\title{
PREREQUISITES FOR ECONOMIC DEVELOPMENT OF TERRITORIES TAKING ACCOUNT OF ECOLOGICAL FACTORS
}

\author{
KUPRIYANCHIK I., PhD ., Associate Professor, \\ National University of Life and Environmental Sciences of Ukraine, Kyiv, \\ kupriyanchik@ukr.net \\ KOLISNYK G., Associate Professor, \\ National University of Life \\ and Environmental Sciences of Ukraine, Kyiv, \\ kolisnyk_g@nubip.edu.ua
}

\begin{abstract}
The problem of the irrational use of the economic, land potential of the territories, the inefficient use of natural resources is considered, and the need for the integrated development of territories, the integral relationship of the regional economy and ecology, and rational nature management, especially in modern conditions, is substantiated.

It has been determined that the policy of rational use of natural resources depends on the level of socio-economic development of the country and the change of indicators of the ecological and economic system should ensure preservation of the natural environment for the present and future generations.

It is proved that for the effective functioning of the ecological and economic system it is necessary to take into account the influence of three main components: society, life, environment.

It is indicated that the problem of improving the efficiency of the ecological and economic system is associated with the analysis of the impact of the economy on the environment and with the problems of choosing the optimal strategy and tactics in managing the economy of the region. To this end, a block diagram has been drawn up reflecting the necessary measures for the rational use of natural resources and environmental protection at the regional level and their content, as well as the directions of the regional environmental and economic policy, as the basis for sustainable development of the state, improving environmental safety and quality of life of the population.
\end{abstract}

Keywords: economic development, environmental factors, ecological and economic systems, socio and economic development.

\section{Formulation of the problem.}

Today, Ukraine's economy is accelerating, but at the same time there are problems related to the transformation processes that are relevant to all regions, which are at the same time the main basis for the formation of a single economic mechanism of the country. For a long period, there was no sound 
regional policy that would be based on the effective use of economic and reproductive potential, as a result, we generally have irrational use of nature, lack of quality infrastructure, low utilization of natural resources. Therefore, scientific substantiation of complex development of territories, holistic interconnection of regional economy and ecology, rational use of nature is actual and necessary.

\section{Analysis of recent research and publications.}

An analysis of recent research and publications has revealed that the problem of irrational use of the economic and land potential of the territories has been reflected in the work of modern scientists. natural resources [5]. Mechanisms for ensuring the environmental security of agricultural land use have been developed [6], the genesis of environmental security has been traced in the context of land relations transformation [7], and an innovative ecological and economic mechanism for the formation of rational use and protection of land resources has been substantiated [8]. However, the problem of the preconditions for the economic development of the territories, taking into account environmental factors, is quite broad and requires further scientific research.

The purpose of the research is to identify directions of regional ecological and economic policy as a basis for sustainable development of the state, improvement of ecological safety and quality of life of the population.

\section{Research methods.}

The theoretical basis of the study is the classical provisions of the economics of environmental management, agrarian economics, environmental and land law, numerous scientific works of domestic and foreign scientists on issues related to the nature of the tasks that are solved in the work. To achieve this goal, we used: general scientific methods of analysis and synthesis, theoretical generalization and comparison in the process of determining the main vectors of the policy of rational use of natural resources, depending on the level of social and economic development of the country.

\section{Results of the study and their discussion.}

An objective condition for the economic development of the territories is the existence of a system of socio-economic relations covering all spheres of production $[3,4,6]$. Scientists and practitioners associate economic development with the growth of well-being, incomes, and quality of life $[4,5,6]$. In turn, the policy on the rational use of natural resources depends on the level of socio-economic development of the country. When creating conditions for the harmonious development of society and nature, which provides comprehensive satisfaction of human needs, new socio-economic problems of environmental protection arise, for which the main ones are environmental and resource conservation measures aimed at preserving the health and comfort of life of the population. Therefore, the tendency of change of indicators of ecological-economic system should be such that conditions for preservation of natural environment for present and future generations are created.

Analyzing the effectiveness of the functioning of the ecological and economic system, it is necessary to take into account the impact of three main 
components: society, life, environment. Society can be characterized by the following indicators: population - number, distribution, natural increase, migration, employment; improving living standards, including maintaining the quality of the environment; health care - public well-being, life expectancy, acclimatization, adaptation, nutrition; living, working, resting conditions; spatial forms of settlement - district, city. As the population grows, the standard of living of the people increases, as well as the requirements for the state and preservation of the environment.

Health care, increasing human life expectancy, assessing opportunities for human adaptation to different environments, ensuring decent living, working, moving, resting are all the main problems for a harmonious development of society.

Life activity includes all aspects of society, both production (mining, mining, construction, transport, agriculture, water) and non-production (services, education, science, culture, administration, food, urban, etc.).

The environment, as the environment of the existence and production activity of mankind, determines the level of anthropogenic impact on the socio-economic development of society, health and living conditions, the development of production and services. The environment is natural, or, depending on the transformation, transformed by man.

Society, life, the environment as components of an ecological and economic system are interconnected.

When studying the processes in the regional ecological and economic system, by which we mean the organizational combination of sustainable technical, economic, environmental, biological and other relationships in the local area, it is necessary to take into ac- count a number of economic, environmental, social indicators of the interconnection of society and nature.

The irrational use of water, land, forest and other resources in our country poses a number of extremely acute problems to modern science and society, on which the pace of further economic growth and the quality of the natural environment depend. The analysis of statistical information shows that the sanitary and hygienic state of the environment is unsatisfactory in almost all the territory of Ukraine, and in particular in the Rivne region, which was chosen for the study of this problem.

According to the Department of Ecology and Natural Resources of Rivne region, Rivne region is a region of Ukraine with a moderate level of environmental pollution, but with a marked tendency to increase technogenic load on it. The main environmental pollutants of the Rivne region are the chemical, woodworking industries, and enterprises for the production of building materials, mechanical engineering, housing and communal services. [10].

The anthropogenic load on the environment of the Plains region is manifested by an increase in the amount of emissions into the atmosphere and discharges into surface water, in the accumulation of waste of all hazard classes.

The peculiarity of the region is the uneven spatial spread of pollution caused by the concentration of industrial enterprises, mainly in Rivne and district centers of the region, as well as the presence of a number of local environmental problems. Overall, in 2017, 9.6 thousand tons of pollutants were released into the air in the region, which is $5.0 \%$ more than in 2016, and unfortunately such a negative trend is observed every year. 
Also, surface water bodies dumped 3.97 million $\mathrm{m} 3$ of return water more than the previous year. A significant proportion of wastewater without treatment or insufficient treatment $[9,10]$.

In 2017, 457.7 thousand tonnes of hazardous wastes were generated in all sectors of the regional economy, which is 255.5 thousand tonnes less than in $2016[9,10]$.

As of 01.01.2018, 310 territories and objects with a total area of 181.5 thousand hectares are assigned to the network of the nature reserve fund, which is $9.05 \%$ of the total area of the region, including 27 objects of the national state area of 64.9 thousand hectares and 283 objects of local value area of 116.6 thousand hectares $[9,10]$.
Therefore, the ecological situation in the region can be described as unstable, which is the result of neglect of objective laws of development and reproduction of the nat ural resource complex over a long period.

The problem of improving the efficiency of the ecological and economic system is related to the analysis of the environmental impact of the economy and the problems of choosing the best strategy and tactics in managing the region's economy. For this purpose, a block diagram is drawn up that reflects the necessary measures for the rational use of natural resources and environmental protection for the Rivne region and their content. (Table 1).

Solving all the above tasks will allow us to carry out a systematic analysis of

\section{Table 1. Necessary measures for rational use of natural resources and environmental protection for Rivne region}

Assessment of ecological and economic efficiency of planned nature conservation measures and theirs priority

1. A system of measures aimed at reducing or eliminating the negative impact of anthropogenic factors.

2. Assessment of environmental performance of environmental measures.

3. Selection and justification of the optimal variant on economic calculations and expert conclusions.

4. Strategic planning and design of environmental measures.

5. Implementation of developments and projects

Economic, and environmental performance of environmental measures; scientific forecasting.

$\downarrow$

1. Integral assessment of the complex impact of economic activity on the environment.

2. Evaluation of integrated economic and environmental performance of environmental measures.

3. Forecast of possible socio-demographic techno-economic and other changes.

4. Priority factors that determine the current ecological status of the environment.

Characteristics of the environment in today's economic environment

1. Territory and borders; management system

2. Natural-historical, socio-demographic conditions.

3. Economic and economic conditions.

4. The main factors of anthropogenic impact on the environment of different sectors of the region's economy.

5. Dynamics and qualitative characteristics of changes in the environment.

6. Characteristics of the influence of a set of local natural, man-made factors on the living conditions and health of the population. 
the functioning of the ecological and economic system and to obtain a quantitative assessment for the management decision, and will also allow to determine the relationship between the state of the ecological system and the level of economy at the present stage and in the future.

\section{Conclusion.}

Today, anthropogenic influence encompasses global natural processes that can change the natural conditions of both the individual region and the entire continent. Therefore, the modern ecological and economic system of using natural resources should be oriented to the use of ecological potential in the interests of socio-economic development of the region and the country as a whole. Obviously, a unified state system of development and implementation of environmental measures should be formed with the possibility for each region to supplement it, taking into account the peculiarities of natural, economic and ethnographic conditions. Therefore, for effective state policy on sustainable environmental management and environmental protection, it is necessary to develop: methodological approaches to solving the problems of rational use of nature and prevention of ecological crisis in the regions; methodological bases of strategic management of environmental activity in industry, agriculture, non-productive sphere, ; theoretical and methodological foundations of socio-economic development of Ukrainian regions in the context of environmental policy.

\section{References}

1. Land Code of Ukraine (2001). Available at: https://zakon.rada.gov.ua/laws/ show/2768-14
2. The Law of Ukraine "On Land Management»/ Available at: https://zakon.rada. gov.ua/laws/show/858-15

3. Dorosh Y., Dorosh O. (2012) Ekoloho-ekonomichni imperatyvy reformuvannia zemelnykh vidnosyn v umovakh rynk. [Ecological and economic imperatives of reforming land relations in market conditions]. Land management newsletter. № 3. S. 30-33

4. Dorosh O.(2017) Terytorialne planuvannia yak chynnyk pidvyshchennia rivnia kapitalizatsii zemel silskykh terytorii. [The territorial planning as a factor in raising the level of capitalization of rural lands] Land management, cadastre and land monitoring. №3-4. S. 42-48.

5. Khvesyk M. A. (2014) Kapitalizatsiia pryrodnykh resursiv: monohrafiia [Capitalization of natural resources]. Kiev. Ukrainy. $268 \mathrm{~s}$.

6. Kupinets L.Y. (2016) Ekolohichna bezpeka ahrarnoho zemlekorystuvannia: teoriia $\mathrm{i}$ mekhanizmy zabezpechennia: monohrafiia. [Ecological security of agricultural land use: theory and mechanisms of provision: monograph] Odesa. $316 \mathrm{~s}$.

7. Kupinets L.Y. (2013) Henezys ekolohichnoi bezpeky $v$ konteksti transformatsii zemelnykh vidnosyn. [The genesis of ecological security in the context of the transformation of land relations]. Economic innovation. Odesa. Ukrainy, Vyp.55. S.221-232.

8. Kuryltsiv R.M.(2006) Ekoloho-ekonomichnyi mekhanizm formuvannia ratsionalnoho vykorystannia i okhorony zemelnykh resursiv (na prykladi Lvivskoi oblasti): avtoref. dys... kand. ekon. nauk: 08.08.01. [Ecological and economic mechanism of formation of rational use and protection of land resources (on the example of Lviv region] Lviv. Ukrainy, $20 \mathrm{~s}$.

9. Development strategy of Rivne region till 2020. Available at: http://www.rv.gov.ua/ sitenew/data/upload/photo/8/strategiya.pdf

10. Report on the state of the environment in Rivne region in 2017. Available at: https:// menr.gov.ua , files , docs , Reg.report 'Rivnenska_dopovid_2016 


\begin{tabular}{l}
\hline \hline *** \\
КУПРіЯНЧИК І.П, КОЛІСНИК Г.М \\
ПЕРЕДУМОВИ ЕКОНОМІЧНОГО РО- \\
ЗВИТКУ ТЕРИТОРІЙ З ВРАХУВАННЯМ ЕКО- \\
ЛОГІЧНИХ ФАКТОРІВ \\
httрS://doi.org/ \\
10.31548/zemleustriy2019.03.07
\end{tabular}

Анотація. Розглянуто проблему нерачіонального використання економічного, земельного потенціалу територій, неесрективного використання природних ресурсів. Обгрунтовано необхідність комплексного розвитку територій, цілісного взаємозв'язку регіональної економіки та екології, раціонального природокористування особливо в сучасних умовах.

Означено, що політика раціонального використання природних ресурсів залежить від рівня соціально-економічного розвитку країни й зміна показників еколого-економічної системи повинна забезпечувати збереження природного середовища для сучасного і майбутнього поколінь.

Доведено, що для ефрективного функціонування еколого-економічної системи необхідно враховувати вплив трьох основних складових: суспільства, життєдіяльності, навколишнього природного середовища.

Наголошено, що проблема підвищення ефрективності еколого-економічної системи пов'язано з аналізом впливу економіки на навколишнє природне середовище та з проблемами вибору оптимальної стратегії і тактики в управлінні економікою регіону. 3 чією метою складена блок-схема, яка відображає необхідні заходи з раціонального використання природних ресурсів та охорони навколишнього середовища на регіональному рівні та ї зміст. Визначено напрями регіональної еколого-економічної політики, як основи для сталого розвитку держави, підвищення екологічної безпеки та якості життя населення.

Ключові слова: економічний розвиток, екологічні фактори, еколого-економічні системи, соціально-економічний розвиток.

\section{*** \\ Куприянчик И.П, Колесник Г.Н. ПРЕДПОСЫЛКИ ЭКОНОМИЧЕСКОГО РАЗВИТИЯ ТЕРРИТОРИЙ С УЧЕТОМ ЭКО- ЛОГИЧЕСКИХ ФАКТОРОВ \\ https://doi.org/ \\ 10.31548/zemleustriy2019.03.07 \\ Рассмотрена проблема нерациональ-} ного использования экономического, земельного потенциала территорий, неэфректтивного использования природных ресурсов и обоснована необходимость комплексного развития территорий, целостного взаимосвязи региональной экономики и экологии, рационального природопользования особенно в современных условиях.

Отмечено, что политика рационального использования природных ресурсов зависит от уровня социально-экономического развития страны и изменение показателей эколого-экономической системы должна обеспечивать сохранение природной среды для настоящего и будущего поколений. Доказано, что для эфрфективного функкционирования эколого-экономической системы необходимо учитывать влияние трех основных составляющих: общества, жизнедеятельности, окружающей природной среды. Обозначено, что проблема повышения эфрфективности эколого-экономической системы связана с анализом влияния экономики на окружающую среду и с проблемами выбора оптимальной стратегии и тактики в управлении экономикой региона. $C$ этой целью составлена блок-схема отражающая необходимые меры по рациональному использованию природных ресурсов и охраны окружающей среды на региональном уровне и их содержание, а также определены направления региональной экол о го-экономической политики, как основы для устойчивого разви тия государства, повышения экологической безопасности и качества жизни населения.

Ключевые слова: экономич еское развитие, экологические фа к торы, эколого-экономические систем ы, сочиально-экономическое развитие. 